\title{
PEMERTAHANAN BAHASA KAYUAGUNG DIALEK PEMATANG PANGGANG MASYARAKAT DESA MAKARTI MULYA KECAMATAN MESUJI KABUPATEN OGAN KOMERING ILIR
}

\author{
Erwin Sawitri \\ SMK Al Hikmah Makarti Mulya, Kec. Mesuji, Kab OKI. \\ erwin.sawitri193@gmail.com
}

\begin{abstract}
Abstrak
Penelitian ini bertujuan mendeskripsikan tingkat pemertahanan bahasa Kayuagung Dialek Pematang Panggang Masyarakat Desa Makarti Mulya Kecamatan Mesuji Kabupaten Ogan Komering llir dan faktor penghambat pemertahanan bahasa Kayuagung Dialek Pematang Panggang. Penelitian menggunakan pendekatan kualitatif dengan teknik pengumpulan data berupa wawancara, angket dan rekam. Hasil penelitian menunjukan bahwa dalam tiga ranah bahasa Kayuagung Dialek Pematang Panggang dapat bertahan dan tiga ranah yang lain bahasa Kayuagung Dialek Pematang Panggang tidak mampu bertahan. Kedua, faktor penghambat pemertahanan bahasa Kayuagung dialek Pematang Panggang, yaitu (1) faktor kedwibahasaan, (2) faktor pernikahan antara etnis yang berbeda, (3) faktor pendidkan yang menambah khasanah masyarakat dan (4) faktor mayoritas Jawa menggerus kebudayaan dan adat-istiadat Kayuagung.
\end{abstract}

Kata Kunci: Pemertahana Bahasa, bahasa Kayuagung dialek Pematang Panggang

\section{Abstract}

This study aims to describe the level of language maintenance Kayuagung Dialek Pematang Panggang Masyarakat Desa Makarti Mulya Kecamatan Mesuji Kabupaten Ogan Komering llir and inhibiting factors of language retention in Kayuagung Pematang Panggang dialect. The study used a qualitative approach with data collection techniques in the form of interviews, questionnaires and records. The results showed that in three domains of language Kayuagung dialect Pematang Panggang can survive and the other three language domains Kayuagung Pematang Panggang dialect unable to hold on. Second, language retention inhibiting factors in Kayuagung Pematang Panggang dialect, that is (1) the bilingual factor, (2) the factor of marriage between different ethnicities, (3) educational factors that add to the repertoire of society, and (4) the majority of Javanese actors eroded the Kayuagung culture and customs

\section{PENDAHULUAN}

a. Latar Belakang Masalah

Peran bahasa Kayuagung dialek Pematang Panggang sebagai bahasa pengantar pada perlahan-lahan mulai digantikan oleh bahasa Jawa ataupun bahasa Indonesia. Berdasarkan pengamatan, pada masyarakat Desa makarti Mulya terlihat adanya perubahan sikap terhadap bahasa Kayuagung Dilaek Pematang Panggang. Banyak Masyarakat yang engan mengajarkan anak-anaknya dengan bahasa Kayuagung dialek
Pematang Panggang, banyak masyarakat penutur bahasa Kayuagung dialek Pematang Panggang di Desa Makarti Mulya menggunakan bahasa Jawa ataupun bahasa Indonesia sebagai bahasa sehari-hari ketika beriteraksi dalam kehidupan sehari-hari. Banyak keluarga muda di daerah pedesaan memutuskan untuk menggunakan bahasa Indonesia sebagai bahasa pertama bagi anak-anak mereka. Hal ini biasanya terjadi pada keluarga-keluarga dengan latar belakang pendidikan tinggi dan sosial 
ekonomi menengah ke atas. Sikap masyarakat yang demikian, merupakan suatu pertanda baik bagi keberadaan bahasa Indonesia sebagai bahasa nasional dan kelestarian bahasa Jawa. Namun, kecenderungan menggunakan bahasa Jawa ataupun bahasa Indonesia sebagai bahasa sehari-hari merupakan pertanda buruk bagi kelestarian bahasa Kayuagung Dialek Pematang Panggang.

Bahasa daerah yakni bahasa Kayuagung Dialek Pematang Panggang memiliki fungsi tersendiri sebagai identitas dan jati diri sebagai orang beretnis Kayuagung. Bahasa Kayuagung dialek Pematang Panggng hidup berdampingan dengan bahasa lain, yaitu bahasa Jawa dan Bahasa Indonesia. Pergeseran bahasa Kayuagung dialek Pematang Panggng pada masyarakat Desa Makarti Mulya menjadi ancaman keberadaan bahasa Kayuagung dialek Pematang Panggng sebagai identitas dan jati diri etnis Kayuagung. Pemertahanan bahasa Kayuagung Dialek Pematang Panggng harus dilakukan oleh masyarakat penutur bahasa Kayuagung dialek Pematang Panggng sendiri agar identitas dan jati diri dari masyarakat etis Katuagung tetap terjaga.

Masyarakat Desa Makarti Mulya Kecamatan Mesuji Kabupaten OKI merupakan masyarakat yang heterogen. Letak geografis yang berada di perbatasan provinsi Sumatera Selatan dan Lampung menyebabkan tingginya mobilitas masyarakat tersebut. Sehingga, menyebabakan banyaknya bahasa yang masuk dan berkembang di dalam masyarakat tersebut. Namun, sebagian besar masyarakat Makarti Mulya tetep mempertahanakan bahasa Kayuagung dialek Pematang Panggng sebagai bahasa ibunya terutama digunakan dalam ranah keluarga. Oleh karna itu, peneliti perlu mengkaji mengenai pemertahanan bahasa Kayuagung Dialek Pematang Panggng di Desa makarti Mulya Kecamatan Mesuji kabupaten OKI.

\section{b. Rumusan Masalah}

Dalam penelitian ini dirumuskan masalah-masalah yang akan dianalisis pada bagian pembahasan. Rumusan masalah tersebut adalah sebagai berikut:
1. Bagaimanakah tingkat pemertahanan bahasa masyarakat Desa Makati Mulya Kecamatan Mesuji Kabupaten Ogan Komering llir?

2. Apakah faktor penghambat pemertahanan bahasa Kayuagung Dialek Pematang Panggang di Desa Makarti Mulya, Kecamatan Mesuji, Kabupaten Ogan Komering Ilir?

\section{c. Tujuan Penelitian}

Penelitian ini bertujuan untuk mendeskripsikan dan menjelaskan hal-hal sebagai berikut:

1. Tingkat pemertahanan bahasa masyarakat desa Makati Mulya Kecamatan Mesuji.

2. Faktor penghambat pemertahanan bahasa Kayuagung Dialek Pematang Panggang di Desa Makarti Mulya, Kecamatan Mesuji, Kabupaten Ogan Komering llir.

\section{KAJIAN TEORITIK}

\section{a. Pemertahanan Bahasa}

Keberadaan bahasa dalam kehidupan manusia mempunyai peranan yang sangat penting. Namun hal ini terkadang kurang begitu dipahami oleh penuturnya, sehingga tidak terasa sebuah peradaban dapat diubah dengan keberadaan suatu bahasa. Disinilah faktor penutur bahasa menentukan keberadaan suatu bahasa di tengah-tengah kehidupa mereka. Dalam masyarakat bilingual dan multilingual ada kemungkinan bahwa kebilingualan atau kemultilingualannya itu lestari. Kesetiaan warganya pada bahasanya masing-masing tinggi. Mereka cenderung dengan bahasa mereka masing-masing meskipun pada kenyataannya sebagian dari mereka ada yang bilingual dan sebagiannya lagi monolingual (Suandi. 2014: 107). Artinya dalam kedwibahasaan terdapat pemertahanan bahasa ibu (B1).

Pergeseran bahasa dan pemertahanan bahasa sebenarnya seperti dua sisi mata uang, bahasa mengeser bahasa lain,atau bahasa yang tergeser oleh bahasa lain. Bahasa yang tergeser adalah bahasa yang tidak mampu mempertahankan diri. Sedangkan dalam pemertahanan bahasa, guyub ini secara kolektif menentukan untuk melanjutkan memakai bahasa yang sudah biasa dipakai( Sumarsono, 2010:231). 
Menurut Suandi. 2014: 107-108 pemertahanan bahasa menyangkut masalah sikap atau penilaian terhadap suatu bahasa, untuk tetap menggunakan bahasa tersebut ditengah-tengah bahasabahasa lainnya. Pemertahanan bahasa lazim didefinisikan sebagai upaya yang disengaja untuk mempertahankan penggunaan bahasa tertentu di tengah ancaman bahasa lain. Dengan kata lain pemertahanan bahasa dimaksudkan untuk (1) mewujudkan diversial kultur, (2) memelihara identitas etnis, (3) memungkinkan adabtabilitas sosial, (4) secara psikologis menambah rasa aman bagi anak, dan (5) meningkatkan kepekaan linguistik.

Sumarsono dan Partana (2002) mengungkapkan bahwa dalam pemertahanan bahasa suatu komunitas secara kolektif menentukan untuk melanjutkan memakai bahasa yang sudah biasa dipakai. Fishman (dalam Syahriani, 2017.vol 23) dalam kajiannya menyatakan bahwa pemertahanan bahasa terjadi tidak semata-mata karena kesetiaan yang tinggi atau perasaan yang kuat terhadap nasionalisme dalam suatu kelompok. Pada masyarakat desa, pemertahanan bahasa cenderung tinggi atau tidak mengalami pergeseran karena faktorfaktor lain.

Berdasarkan pendapat para ahli dapat disimpulkan bahwa pemertahanan bahasa merupakan suatu sikap atau penilaian terhadap suatu bahasa untuk tetap setia menggunakan bahasa asli atau bahasa ibu (B1) di tengah-tengah masuknya dan berkembangnya berbagai bahasa lain dalam interaksi sosial masyarakat.

\section{b. Bahasa Kayuagung Dialek Pematang Panggang}

Suku dan bahasa daerah yang ada di Sumatera Selatan khususnya Ogan Komering llir dipengaruhi oleh Puyang yaitu figur yang paling menonjol dan dapat ditemui hampir di setiap tempat dalam wilayah Ogan Komering llir. Tokoh ini dipercaya sebagai cikal bakal masyarakat setempat. Pada umumnya, penduduk yang mendiami daerah Ogan Komering Ilir adalah suku Melayu Palembang, dengan varian Pegagan, Penesak, Rambang Senuling, terdapat pula suku Komering
Kayuagung. Sementara itu, suku Komering dan Kayuagung memiliki bahasa tersendiri yang tidak dapat dilihat perubahannya, karena penuturan dalam bahasa Ogan Komering llir ini tidak dikenal tingkatan bahasa sebagaimana di Jawa ada bahasa ngoko, kromo dan inggil. Dengan demikian, daerah Kayuagung Kabupaten Ogan Komering llir, berdasarkan sejarahnya, wilayah Kayuagung terdiri dari sembilan marga (Morge Siwe) setingkat desa/kelurahan, yaitu Kelurahan Kayuagung (asli), Perigi, Kutaraya, Kedaton, Sukadana, Paku, Mangun Jaya, Sidakersa, dan Jua-Jua. Sembilan marga (Morge Siwe). seiring dengan perkembangan zaman maka wilayah Kayuagung ini bertambah jumlah penduduknya hingga menjadi seperti sekarang.

Bahasa Kayuagung yang terdapat di Sumatera Selatan terdiri dari sembilan dilaek, yaitu (1) dialek Lintang, (2) dialek Kimak, (3) dialek Pagar Dewa, (4) dialek Pematang, (5) dialek Penesak, (6) dialek kayuagung Perigi, (7) dialek Lubuk rumbai, (8) dialek Kikim, (9) dialek Ngulak. Dialek Pematang dituturkan di Desa Pematang Panggang Kecamatan Mesuji Kabupaten Ogan Komering llir (OKI) dan penutur yang berada sekita Desa Pematang Panggang salah satunya Desa Makarti Mulya. Berdasarkan hasil perhitungan, persentase perbedaan kesembilan dialek 51\%-80\%. Isiolek Kayuagung merupakan sebuah bahasa dengan persentase perbedaan berkisar $81-100 \%$ jika dibandingkan dengan bahasa Melayu, komering, Lematang, Ogan dan Pedamaran (Balai Bahasa, 2017).

\section{METODE PENELITIAN \\ a. Metode Penelitian}

Metode penelitian yang digunakan dalam penelitian ini adalah metode kualitatif. Penelitian bertujuan untuk memahami fenomena yang dialami oleh subjek penelitian secara deskriptif. Data yang diperoleh dari penelitian ini tidak berupa angka-angka tetapi data yang terkumpul berbentuk kata-kata lisan yang mencakup catatan dan laporan.

\section{B. Lokasi Penelitian}

Lokasi penelitian adalah tempat berlangsungnya penelitian. Adapun lokasi 
pada penelitian ini adalah di desa Makarti Mullya, Kecamatan Mesuji, Ogan Komering llir. Alasan memilih lokasi tersebut karena sebagian besar masyarakatnya merupakan masyarakat Jawa yang menggunakan bahasa Jawa dan sebagian menggunakan bahasa Kayuagung dialek Pematang Panggang sebagai bahasa ibu tetapi daerah ini berada dalam lingkungan kultur Jawa.

\section{Sumber Data Penelitaian}

Arikunto (2010:172) menjelaskan bahwa sumber data dalam penelitian adalah subjek dari mana data dapat diperoleh. Adapun sumber data penelitian adalah pengguna bahasa Kayuagung dialek Pematang Panggang di Desa Makarti Mulya, di wilayah Kabupaten Ogan Komering llir, Provinsi Sumatera Selatan. Sumber data pada penelitian ini diperoleh melalui informan yaitu, masyarakat pengguna bahasa Kayuagng Diaek Pematang Panggang di Desa Makarti Mulya. Informan yang harus memenuhi syarat yang ditentukan.

\section{Instrumen Penelitian}

Instrumen penelitian adalah alat penelitian (Sugiyono, 2013: 305). Instrumen yang digunakan peneliti dalam penelitian ini adalah menggunakan Pedoman wawancara dengan mengajukan beberapa pertanyaan kepada informan yang bertujuan untuk memperoleh gambaran mengenai penggunaan bahasa dan pemertahanan bahasa serta koesioner atau angket yang telah disiapkan oleh penelitin .

\section{E. Teknik Pengumpulan Data}

Dalam penelitian ini data diperoleh dengan menggunakan teknik pengumpulan data sebagai berikut:

\section{Teknik Simak Bebas Libat Cakap}

Penjaringan data dapat dilakukan denga menyimak penggunaan bahasa tanpa ikut bepartisipasi dalam proses pembicaraan. Dalam teknik ini, peneliti tidak dilibatkan langsung untuk ikut menentukan pembentukan dan pemunculan calon data kecuali hanya sebagai pemerhati terhadap calon data yang terbentuk dan muncul dari peristiwa kebahasaan yang berada diluar dirinya (Kesuma. 2007: 44). Dalam penelitian ini peneliti menyimak pembicaraan yang dilakukan oleh masyarakat Makarti Mulya yang mengunakan bahasa Kayuagung dialek Pematang Panggang.

\section{Teknik Rekam}

Teknik rekam ini merupakan teknik yang sifatnya melengkapi penyediaan data pada teknik catat, teknik catat ini dapat dicek kembali dengan rekaman yang dihasilkan, sehingga dapat memberikan hasil yang baik (Mahsun, 2017:134). Adapun data yang peneliti rekam ialah percakapan masyarakat Makarti Mulya yang menggunakan Kayuagung dialek Pematang Panggan.

\section{Teknik Koesioner}

Angket menurut Arikunto (2010:151) adalah pernyataan tertulis yang digunakan untuk memperoleh informasi dari responden dalam arti laporan atau sesuatu yang diketahui oleh responden. Pada penelitian ini peneliti menggunakan koesioner untuk memeperoleh data dengan 35 pertanyaan menggenai pemertahanana bahasa yang dijawab oleh responden. Data yang diperoleh berdasarkan hasil jawaban respoden diolah dan ditarik kesimpulan.

\section{PEMBAHASAN}

\section{a. Kategori Dan Tingkat Pemertahanan Bahasa Kayuagung Dialek Pematang Panggang}

Tingkat penggunaan bahasa pada masing-masing lingkup tersebut akan dipaparkan sebagai berikut.

\section{Lingkup Kekeluargaan}

Tabel 4.1 Tingkat Penggunaan Bahasa

Kayuagung Lingkungan Keluarga

\begin{tabular}{|c|l|l|l|l|l|l|l|}
\hline No & $\begin{array}{l}\text { Lawan } \\
\text { Bicara }\end{array}$ & $\mathbf{F}$ & $\begin{array}{l}\text { BKP } \\
(\%)\end{array}$ & $\mathbf{F}$ & $\begin{array}{l}\text { BJ } \\
(\%)\end{array}$ & $\mathbf{F}$ & $\mathbf{B I}(\%)$ \\
\hline 1. & $\begin{array}{l}\text { Orang } \\
\text { Tua }\end{array}$ & 18 & 90 & 0 & 0 & 2 & 10 \\
\hline 2. & $\begin{array}{l}\text { Suami- } \\
\text { istri }\end{array}$ & 17 & 85 & 3 & 15 & 0 & 0 \\
\hline 3. & $\begin{array}{l}\text { Anak- } \\
\text { anak }\end{array}$ & 17 & 85 & 3 & 15 & 0 & 0 \\
\hline
\end{tabular}

Tabel di atas menunjukkan bahwa tingkat pemertahanan bahasa Kayuagung Dialek Pematang Panggang di dalam lingkungan keluarga, khususnya ketika responden berbicara dengan kedua orang tua menunjukan persentase yang sangat tinggi jika dibandingkan dengan tingkat penggunaan bahasa Jawa dan bahasa Indonesia. Dari 20 responden yang terlibat dalam penelitian ini, tingkat penggunaan bahasa Kayuagung Dialek Pematang Panggang kepada orang tua sebesar 
$90 \%$, tingkat penggunaan pada suamiistri $85 \%$ dan anak-anak $85 \%$, Adanya penggunaan bahasa Jawa dan bahasa Indonesia karena dipengaruhi oleh masyarakat Desa Makarti Mulya merupakan masyarakat dwibahasa atau anekabahasa.

\section{Lingkup Ketetanggaan}

Tabel 4.2 Tingkat Penggunaan Bahasa

Kayuagung Lingkungan Keluarga

Data pada tabel di atas menunjukkan bahwa masyarakat penutur bahasa Kayuagung dialek Pematang Panggang ketika lawan tutur mereka orang dewasa atau bahkan orang tua, sebanyak 15 (75\%) responden tetap berkomuniksi dan berinteraksi dengan menggunakan bahasa Kayuagung dialek Pematang Panggang. Semetara 5 (25\%) responden lainnya memilih menggunkan bahas Jawa dan pada lawan tutur anakanak 9 (45\%) responden menggunakan bahasa Kayuagung, 10 responden (50\%) menggunkanan bahasa Jawa. Hal ini, dikerenakan tetangga responden kebanyakan orang Jawa. Sehingga, mereka belajar dan berinteraksi menggunkana bahasa.

\section{Lingkup Persahabatan}

Tabel 4.3 Tingkat Penggunaan Bahasa Kayuagung Lingkungan Keluarga

\begin{tabular}{|c|l|c|c|c|c|c|c|}
\hline No & Subjek & $\mathbf{F}$ & $\begin{array}{c}\text { BKP } \\
(\%)\end{array}$ & $\mathbf{F}$ & $\begin{array}{c}\text { BJ } \\
(\%)\end{array}$ & $\mathbf{F}$ & $\mathbf{B I}(\%)$ \\
\hline $\mathbf{1 .}$ & $\begin{array}{l}\text { Orang } \\
\text { Tua }\end{array}$ & 17 & 85 & 3 & 15 & 0 & 0 \\
\hline $\mathbf{2 .}$ & $\begin{array}{l}\text { Anak- } \\
\text { anak }\end{array}$ & 13 & 65 & 3 & 15 & 4 & 20 \\
\hline
\end{tabular}

Tabel di atas menggambarkan bahwa pada orang tua masyarakat penutur bahasa Kayuagung Dialek Pematang Panggang lebih dominan penggunaan bahasa Kayuagung dalek Pematang Panggang dibandingkan anakanak pada ruang lingkup persahabatan, dan beberapa menggunakan bahasa Jawa karena teman-teman mereka juga berasal dari etnis Jawa. Jika dilihar dari persentasenya dari 20 responden pada orang tua sebanyak $17(85 \%)$ responden dan $13(65 \%)$ tetap menggunkan bahasa Kayuagung Dialek Pematang Panggang dalam ruang lingkup persahabatan. Sementara sebanyak 3(15) responden pada orang tua dan anak-anak menggunkan bahasa Jawa, karena teman-teman mereka tidak hanya berasala dari etnis kayuagung tapi lebih banyak berasal dari etnis Jawa.

\section{Lingkup Pemerintahan}

Tabel 4.4 Penggunaan Bahasa pada Lingkup Pemerintahan di Desa Makarti

\begin{tabular}{|l|l|c|c|}
\hline No & Bahasa & Frekuensi & $(\%)$ \\
\hline $\mathbf{1}$ & $\begin{array}{l}\text { Bahasa } \\
\text { Kayuagung } \\
\text { Dialek Pematang }\end{array}$ & 0 & 0 \\
\hline $\mathbf{2}$ & Bahasa Jawa & 8 & 40 \\
\hline
\end{tabular}

\begin{tabular}{|c|c|c|c|c|c|c|c|}
\hline No & $\begin{array}{l}\text { Lawan } \\
\text { Bicara }\end{array}$ & $\mathbf{F}$ & $\begin{array}{l}\text { BKP } \\
(\%)\end{array}$ & $\mathbf{F}$ & $\begin{array}{l}\text { BJ } \\
(\%)\end{array}$ & $\mathbf{F}$ & $\mathrm{BI}(\%)$ \\
\hline 1. & $\begin{array}{l}\text { Orang } \\
\text { Tua }\end{array}$ & 15 & 75 & 5 & 35 & 0 & 0 \\
\hline 2. & $\begin{array}{l}\text { Anak- } \\
\text { anak }\end{array}$ & 9 & 45 & 10 & 50 & 1 & 5 \\
\hline 3 & \multicolumn{3}{|c|}{$\begin{array}{l}\text { Bahasa } \\
\text { Indonesia }\end{array}$} & & \multicolumn{2}{|l|}{12} & 80 \\
\hline \multicolumn{4}{|c|}{ Jumlah } & & 20 & & 100 \\
\hline
\end{tabular}

Tabel di atas menunjukkan bahwa penggunaan bahasa pada ruang lingkup pemerintahan yang terjadi di kantor desa Makarti Mulya terlihat lebih dominan pada penggunaan bahasa Indonesia yakni sebesar $60 \%$ atau sebanyak 12 orang, sebesar $40 \%$ atau sebanyak 8 orang mengaku menggunakan bahasa Jawa. Kondisi tersebut menunjukkan bahwa masyarakat penutur bahasa Kayuagung Dialek Pematang Panggang (etnis Kayuagung) memiliki toleransi interaksi sosial di dalam kepentingan pemerintahan. Hal ini dikarenaka kepala desa yakni ibu H. Sri Surani, S.Pd. serta staff desa yang ada di kantor desa Makarti Mulya berasal dari etnis Jawa dan sama sekali tidak memahami bahasa Kayuagung dialek Pematang Panggang. Sehingga, bagi masyarakat pengguna bahasa Kayuagung dialek Pematang Panggang (etnis Kayuagung) ketika berurusan denaga Kepala Desa atau urusan di kantor desa akan menggunkan bahasa Jawa. Akan tetapi, bagi masyarakat penutur bahasa Kayuagung dialek Pematang Panggang yang tidak bisa menggunkan bahasa Jawa biasanya menggunkan Bahasa Indonesia.

\section{Lingkup Transaksi}

Tabel 4.5 Penggunaan Bahasa pada Lingkup Transaksi

\begin{tabular}{|l|l|l|l|l|l|l|l|}
\hline $\begin{array}{l}\mathbf{N} \\
\mathbf{o}\end{array}$ & $\begin{array}{l}\text { Tempat } \\
\text { Transak } \\
\text { si }\end{array}$ & $\mathbf{F}$ & $\begin{array}{l}\text { BK } \\
\mathbf{P} \\
\text { (\%) }\end{array}$ & $\mathbf{F}$ & $\begin{array}{l}\text { BJ } \\
(\%\end{array}$ & $\mathbf{F}$ & $\begin{array}{l}\text { BI( } \\
\text { \%) }\end{array}$ \\
\hline 1. & $\begin{array}{l}\text { Pasar } \\
\text { Tradisio }\end{array}$ & 3 & 15 & 4 & 20 & 1 & 65 \\
\hline
\end{tabular}




\begin{tabular}{|l|l|l|l|l|l|l|l|}
\hline & nal & & & & & & \\
\hline 2. & Warung & $\begin{array}{l}1 \\
2\end{array}$ & 60 & 6 & 30 & 2 & 10 \\
\hline
\end{tabular}

Tabel di atas menunjukkan adanya perbedaan yang mencolok penggunaan bahasa pada lingkup transaksi yang terjadi di pasar tradisional desa Makarti Mulya dan di warung Pasaran blok $F$ Perbedaan pertama terlihat pada penggunaan bahasa Kayuagung Dialek Pematang Panggang dan bahasa Indonesia di pasar tradisional, penggunaan bahasa Indonesia terlihat lebih dominan daripada penggunaan bahasa Kayuagung Dialek Pematang Panggang. Hal ini terjadi karena letak pasar tradisional yang menyediakan bahan-bahan kebutuhan sehari-hari berada di wilayah pemukiman mayoritas masyarakat etnis Jawa yakni di blok $D$ desa Makarti Mulya dan sebagian besar pedagangnya berasal dari etnik Jawa. Hal ini membuat penutur bahasa Kayuagung menggunkan bahasa selain bahasa Kayuagung Dialek Pematang Panggang.. Perbedaan kedua, yakni pada penggunaan bahasa Kayuagung Dialek Pematang Panggang di warung pasaran blok $F$ terlihat lebih dominan daripada penggunaan bahasa Jawa. $\mathrm{Hal}$ ini dipengruhi letak warung warung Pasaran blok $F$ yang terletak di blok $F$ yang terdapat banyak masyarakat pengguna bahasa Kayuagung dialek Pematang Panggang menjadikan pedangan di warung warung Pasaran Blok $F$ pahan dan dapat berbahasa menggunkan bahasa Kayuagung Dialek Pematang Panggang. Berdasarkan tabel dan akumulasi persentase diperoleh angka $37,5 \%$ tersebut merupakan angka yang cukup rendah dan menunjukan bahawa pemertahanan bahasa kayuagung Dialek Pematang Panggang dapat dikatakan tidak bertahan dan telah mengalami pergeseran pada ranag transaksi.

6. Lingkup Keagamaan

Tabel 4.5 Penggunaan Bahasa pada Lingkup Transaksi

\begin{tabular}{|l|l|l|l|l|l|l|l|}
\hline $\begin{array}{l}\mathbf{N} \\
\mathbf{0}\end{array}$ & Tempat & $\begin{array}{l}\mathbf{F} \\
\mathbf{B K} \\
\mathbf{P} \\
\mathbf{( \% )}\end{array}$ & $\begin{array}{l}\mathbf{F} \\
\mathbf{B J}\end{array}$ & $\begin{array}{l}\mathbf{F} \\
\mathbf{( \%}\end{array}$ & $\begin{array}{l}\mathbf{B C} \\
\mathbf{\%})\end{array}$ \\
\hline 1. & $\begin{array}{l}\text { Khutbah } \\
\text { di Masjid }\end{array}$ & 0 & 0 & 1 & 85 & 3 & 15 \\
\hline 2. & Pengajia & 0 & 0 & 1 & 80 & 4 & 20 \\
\hline
\end{tabular}

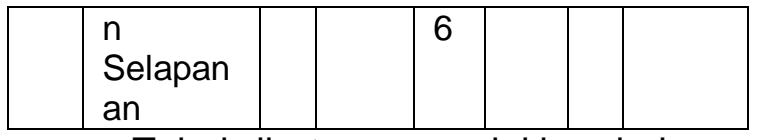

Tabel di atas menunjukkan bahwa penggunaan bahasa Jawa terlihat lebih dominan ketika khutbah di masjid, sesuai hasil wawancara kepada informan, hal ini terjadi dikarenakan sebagian besar masyarakat Desa Makarti Mulya beretnis Jawa dan berbahasa Jawa, sehingga tidak memungkinkan penggunaan bahasa Kayuagung dialek Pematang Panggang dalam acara keagamaan seperti khutbah atau ceramah-ceramah di masjid. Hal senada ini dengan kegiatan keagamaan lainnya yakni kegiatan keagamaan seperti Selapanan yang rutin diadakan setiap sebulan sekali secara bergilir mulai dari blok A-G di desa Makarti Mulya. Bahasa yang digunkan dalam pengajian tersebut menggunkan bahasa Jawa. Penggunaan bahasa Juwa juga dilatarbelakangi oleh banyaknya pemuka agama yang di undang dan didaulat sebagai pengisi acara ceramah agama merupakan pemukaagama yang berasal dari Jawa atau berasal dari Lampung yang beretnis Jawa. Sehingga, ketika pengajian ataupun ceramah agama bahasa yang digunakan adalah bahasa Jawa.

\section{B. Faktor-faktor Penghambat Pemertahanan Bahasa Kayuagung Dialek Pematang Panggang di Desa Makarti Mulya}

\section{Faktor Kedwibahasaan atau Keanekabahasaan}

Faktor penghambat pemertahanan bahasa bahasa Kayuagung dialek Pematang Panggag di desa Makarti Mulya, Kecamatan Mesuji, Kabupaten Ogan Komering llir, yaitu adanya faktor kedwibahasaan atau keanekabahasaan. $\mathrm{Hal}$ ini terjadi karena masyarakat Desa Makarti Mulya, Kecamatan Mesuji, Kabupaten Ogan Komering Ilir mayorita berbahasa Jawa dan hanya sebagian kecil masyarakat yang menggunkan bahasa Kayuagung dialek Pematang Panggang, oleh karena hal tersebut, masyarakat penutur bahasa Kayuagung dialek pematang panggang tidak hanya menggunakan dan menguasai satu bahasa, namun mereka dapat pula menggunakan dua bahasa atau lebih ketika berkomunikas berkomunikasi dan 
berinteraksi dalam kehidupan sehari-hari. Dari hasil penelitian, bahasa Kayuagung dialek pematang panggang merupakan bahasa minoritas dan berdampingan dengan bahasa-bahasa lain yang tergolong bahasa mayoritas yakni bahasa Jawa.

Menurut informasi yang didapatkan dari informan, masyarakat penutur bahasa Kayuagung Dialek Pematang Panggang di Desa Makarti Mulya akan menggunakan bahasa Jawa jika berkomunikasi dan berinteraksi dengan masyarakat beretnis Jawa dan menggunakan bahasa Kayuagung Dialek Pematang Panggang jika berbicara dengan orang yang beretnis Kayuagung, hal tersebut terjadi karena adanya unsur kebudayaan dan unsur ekonomi yang melatarbelakangi pemakaian bahasa. sebagian besar pedagang yang terdapat di desa Makarti Mulya merupakan masyarakat beretnis Jawa dan menggunkan bahasa Jawa dalam kehidupan sehari-hari. Selain itu Mata pencaharian masyarakat Desa Makarti Mulya sebagian besar adalah petani sawit dan sebagian kecil adalah petani karet. Sebagian besar masyarakat Jawa menjadi buruh atau bekerja kepada masyarakat penutur bahasa Kayuagung, oleh karena hal tersebut, secara bersamaan terjadi pengaruh penggunaan bahasa oleh masyarakat Jawa kepada masyarakat penutur bahasa Kayuagung dialek Makarti Mulya, yakni terjadinya kedwibahasaan.

\section{Faktor Pernikahan Antaretnik yang Berbeda}

Pernikahan antaretnik yang berbeda menjadi faktor yang cukup mempengaruhi terhadap pemertahanan Kayuagung Dialek Pematang Panggang di Desa Makarti Mulya Kecamatan Mesuji, Kabupaten Ogan Komering Ilir. Faktor tersebut dapat membawa akibat pada keberadaan dan kelangsungan hidup bahasa tradisional (bahasa ibu/bahasa daerah), apabila dalam sebuah keluarga berasal dari etnik yang sama, maka tidak akan ada kesulitan untuk menentukan bahasa ibu yang digunakan dalam kehidupan sehari-hari, ataupun bahasa yang akan diajarkan kepada anak-anak mereka. Akan tetapi, perbedaan etnik dalam pernikahan akan menimbulkan kesulitan bagi kedua orang tua untuk memilih menggunakan bahasa manakah yang akan menjadi bahasa ibu bagi anakanaknya, apakah memilih mengajarkan bahasa dari ayah mereka atau mengajarkan bahasa dari ibu mereka. Bahkan kedua bahasa tersebut dapat digunakan dalam kehidupan sehari-hari atau memilih untuk mengajarkan bahasa lain seperti bahasa Indonesia. Hal ini tentu saja menjadi penghambat pemertahanan suatu bahasa.

\section{Faktor Pendidikan Menambah Khasanah Bahasa Masyarakat}

Pada ruang lingkup pendidikan, baik Sekolah Dasar (SD), pendidikan Sekolah Menengah Pertama (SMP), pendidikan Sekolah Menengah Atas (SMA) yang terdapat di Desa Makarti Mulya tidak ada mata pelajaran bahasa Daerah yang kemudian di sesuikan dengan bahasa daerah masing-masing tiap daerah seperti halnya yang terdapat pada kurikulum terdahulu. Akan tetapi, tidak menutup kemungkinan terjadi penggunaan bahasa daerah pada saat proses kegianatan belajar mengajar. Penggunaan bahasa daerah Pada proses kegiatan belajar mengajar terjadi karena bahasa daerah dijadikan bahasa pengantar pada proses kegiatan belajar mengajar. Bahkan terdapat beberapa guru yang masih aktif menggunkan bahasa daerah (Jawa) pada saat proses kegiatan belajar mengajar. Hal tersebut menjadi salah satu faktor penghambat pemertahanan bahasa Kayuagung Dialek Pematang Panggang. Siswa yang berasal dari luar etnis Jawa (penutur bahasa Kayuagung Dialek Pematang Panggang) terpaksa harus belajar dan memahami bahasa Jawa

\section{Mayoritas Adat Jawa Menggerus Adat Istiadat Kayuagung}

Faktor mayoritas atau banyaknya suku Jawa turut menjadi penghambat pemertahanan bahasa Kayugung Dialek Pematang Panggang di Desa Makarti Mulya Kecamatan Mesuji Kabupaten Ogan Komering Ilir. Kebudayaan atau adat Istiadat yang ada di Desa Makarti Mulya seperti wetonan, tingkepan dan ngapati yang isinya selain doa keselamatan ialah puji pujian yang menggunkan bahasa Jawa. Selain adat istiadat, kesenian di Desa makarti Mulya 
banyak berasal dari Jawa seperti kuda lumping, reok serta jaranan dimana sinden yang mengiringi permaian tersebut menggunkan bahasa Jawa.

Kuat dan mengakarya kebudayaan dan adat istiadat Jawa di desa Makarti Mulya membuat kebudayaan dan adat istiadat etnis Kayuagung mulai tergerus dan lama kelamaan ditinggalkan oleh masyarakat etnis Kayuagung. Menurut Ahmad Nasir (63 tahun) salah satu masyarakat penutur bahasa Kayuagung dialek Pematang Panggang yang sudah sejak lahir telah tinggal di desa Makrti Mulya mengatakan bahwa kebudayaan dan adat istiadat masyaraat Jawa yang mengakar mempegaruhi keberadaan kebudayaan dan adat istiadat masyarakat penutur bahasa Kayuagung Dialek Pematang Panggang. salah satunya adalah tidak dipakainya lagi adat istiadat seperti ngoni cangkingan (memberi bawaan), moyot mulah bujang gades sudah mulai ditinggalkan oleh masyarakat etnis Kayuagung.

\section{PENUTUP}

\section{a. Kesimpulan}

Dalam kajian ini, pemertahanan bahasa Kayuagung dialek Pematang Panggang di Desa Makarti Mulya, Kecamatan Mesuji, Kabupaten Ogan Komering llir, dapat dilihat dari tingkat pemertahanan bahasa bahasa Kayuagung dialek Pematang Panggang yang terlihat masih tetap bertahan namun dalam jumlah yang rendah. Hal ini disebabkan beberapa faktor yang menghambat pemertahanan bahasa Kayuagung dialek Pematang Panggang,

Tingkat pemertahanan bahasa Kayuagung dialek Pematang Panggang di Makarti Mulya dapat dilihat dari tingkat penggunaan bahasa Kayuagung dialek Pematang Panggang oleh masyarakat penuturnya, penggunaan tersebut dibatasi pada beberapa lingkup, yakni (1) lingkup kekeluargaan, (2) lingkup ketetanggaan, (3) lingkup pemerintahan, (4) lingkup persahabatan, (5) lingkup transaksi, dan (6) lingkup keagamaan. Dilihat dari keenam lingkup tersebut, tingkat pemertahanan bahasa Kayuagung dialek Pematang Panggang paling dominan terjadi pada lingkup kekeluargaan karena pada lingkup ini BKP digunakan dalam interaksi sehari-hari dan penggunaan bahasa Kayuagung dialek Pematang Panggang paling rendah yaitu pada lingkup keagamaan (khutbah di masjid), hal ini terjadi karena sebagian besar masyarakat Desa Makarti Mulya berbahasa Jawa, sehingga tidak memungkinkan penggunaan bahasa Kayuagung dialek Pematang Panggang dalam acara keagamaan seperti khutbah atau ceramah-ceramah di masjid.

Faktor-faktor

penghambat pemertahanan bahasa Kayuagung dialek Pematang Panggang di Makarti Mulya yakni, (1) faktor kedwibahasaan atau keanekabahasaan, (2) faktor pernikahan antaretnik yang berbeda, dan (3) faktor pendidikan. Ketiga faktor tersebut memiliki kadar yang sama untuk menghambat pemertahanan bahasa Kayuagung dialek Pematang Panggang di Makarti Mulya,

\section{DAFTAR PUSTAKA}

Arikunto, Suharsimi. 2010. Prosedur Penelitian Suatu Pendekatan Praktik. Jakarta: Rineka Cipta.

Badan Pengembangan dan Pembinaan Bahasa Kementrian Pendidikan dan Kebudayaan. 2017. Bahasa dan Peta Bahasa. Online. http://118.98.223.79/petabahasa/info bahasa2.php?idb=29\&idp=Sumatra \%20Selatan

Kesuma, Tri mastoyo jati. 2007. Pengantar (Metode) Penelitian Bahasa, Yogyakarta: Carasvatibooks.

Mahsun. 2017. Metode Penelitian Bahasa: Tahapan Strategi, Metode dan Tekniknya. Jakarta: PT Raja Grafindo Persada.

Suandi, I Nengah. 2014. Sosiolinguistik Yogyakarta: Graha ilmu

Sugiyono. (2013). Metode Penelitian Pendidikan: Pendekatan Kuantitaif, Kualitatif, dan R\&D. Bandung: Alfabeta. 
Sumarsono. 2010. Sosiolinguistik.

Yogyakarta: Pustaka Pelajar.

Sumarsono dan Paina Partana. 2002.

Sosiolinguistik. Yogyakarta: Penerbit Sabda.

Syahriani. Alfi. 2017. Pemertahanan Bahasa Jawa dialeg Banten Pada Guyub Tutur di Kelurahan Sumur Pecung Serang bit.ly/buletinnalturas. Vol XXIII. No 2, Juli 2017. ISSN:0853-1692. http://www.researchgate/publicati on/321536312 Pemertahanan B ahasa Jawa Dialek Banten pad a Guyub Tutur di Kelurahan $\mathrm{S}$ umur Pancung Serang/amp 